NBER WORKING PAPER SERIES

\title{
LEVERAGE AND ASSET BUBBLES: AVERTING ARMAGEDDON WITH CHAPTER 11?
}

\author{
Marcus Miller \\ Joseph E. Stiglitz \\ Working Paper 15817 \\ http://www.nber.org/papers/w15817
NATIONAL BUREAU OF ECONOMIC RESEARCH
1050 Massachusetts Avenue
Cambridge, MA 02138
March 2010

We thank seminar and conference participants for their comments, especially John Driffill, Sayantan Ghosal, Peter Hammond, Anton Korinek, Chris Kubelec, Michael McMahon, Tomo Ota, Herakles Polemarchakis, Mathan Satchi, David Vines and Lei Zhang. Miller is grateful for the opportunity provided by a Houblon Norman Fellowship to work on this topic at the Bank of England; Han Hao Li and Ashwin Moheeput are thanked for research assistance. The views expressed are those of the authors, however, and not necessarily those of the Bank of England or the National Bureau of Economic Research.

NBER working papers are circulated for discussion and comment purposes. They have not been peerreviewed or been subject to the review by the NBER Board of Directors that accompanies official NBER publications.

(C) 2010 by Marcus Miller and Joseph E. Stiglitz. All rights reserved. Short sections of text, not to exceed two paragraphs, may be quoted without explicit permission provided that full credit, including $\odot$ notice, is given to the source. 
Leverage and Asset Bubbles: Averting Armageddon with Chapter 11 ?

Marcus Miller and Joseph E. Stiglitz

NBER Working Paper No. 15817

March 2010

JEL No. E32,G21,G32,G33,G34

\title{
ABSTRACT
}

An iconic model with high leverage and overvalued collateral assets is used to illustrate the amplification mechanism driving asset prices to 'overshoot' equilibrium when an asset bubble bursts - threatening widespread insolvency and what Richard Koo calls a 'balance sheet recession'.

Besides interest rates cuts, asset purchases and capital restructuring are key to crisis resolution. The usual bankruptcy procedures for doing this fail to internalise the price effects of asset 'fire-sales' to pay down debts, however. We discuss how official intervention in the form of 'super' Chapter 11 actions can help prevent asset price correction causing widespread economic disruption.

\author{
Marcus Miller \\ University of Warwick \\ Department of Economics \\ Coventry \\ CV4 7AL \\ United Kingdom \\ marcus.miller@warwick.ac.uk \\ Joseph E. Stiglitz \\ Uris Hall, Columbia University \\ 3022 Broadway, Room 814 \\ New York, NY 10027 \\ and NBER \\ jes322@columbia.edu
}


"There are more things in heaven and earth, Horatio, than are dreamt of in your philosophy." Hamlet

From 2007 to 2009 a chain of events, beginning with unexpected losses in the US sub-prime mortgage market, was destined to bring the global financial system close to collapse and to drag the world economy into recession. "One of the key challenges posed by this crisis," says Williamson (2009) "is to understand how such major consequences can flow from such a seemingly minor event." Before describing an amplification mechanism involving overpriced assets and excessive leverage, we begin by looking, albeit briefly, at what the current macroeconomic paradigm may have to say.

The canonical New Keynesian/New Classical macroeconomic model, as outlined in Woodford's Interest and Prices (2003) for example, focuses on using interest rates to control inflation in a setting where the private sector optimises inter-temporally but wages and prices are relatively inflexible. Under the convenient assumption of a representative agent with rational expectations, credit flows and leverage are left out of the picture, however. As Bean (2009) ruefully observes in his Schumpeter lecture to the EEA, "there are no financial frictions to speak of, [and] financial intermediation plays a negligible role in Mike Woodford's magisterial state-of-the-art opus."

Even when heterogeneity as between lenders and borrowers is taken into account, and some financial friction - in the form of a 'wedge' or spread between the rate charged to borrowers and that paid to lenders-is introduced, the key policy implications are not much changed, it seems, as long as the spread is accommodated by prompt adjustment in policy rates. What Cúrdia and Woodford had to say at the Bank of International Settlements in June 2008 was summarised by the Chief Economist at the IMF as follows: "The effects of a worsening of financial intermediation, they tell us, are likely to be limited. Changes in the wedge have important distribution effects, but small aggregate effects. Monetary policy still works. Indeed, optimal monetary policy remains simple," Blanchard (2008). 
Others were less sanguine: the experience of Japan in the 1990s, for instance, led Richard Koo (2008) to warn that the credit crunch would be followed by a protracted process of de-leveraging and that radical policy easing was needed to combat a "balance sheet recession." The actual response of monetary and fiscal policy has in fact been dramatic - including near-zero policy rates and extraordinary official intervention to prevent the collapse of the financial system, amounting to around three quarters of GDP in the U.K. and U.S. for example.

This may be, as the Governor of the Bank of Japan suggested at the Jackson Hole conference, "a good time to review the prevailing philosophy in the light of the current crisis," Shirakawa (2009). The Wicksellian perspective that Woodford advocates has surely freed monetary economics from some of the simpler nostrums of Friedman's Monetarism; but the macroeconomic models it has encouraged central bankers to use - with their representative agents, rational expectations, small shocks, missing banking sector, etc.- - seem to miss the point: that things can suddenly go badly wrong so that emergency measures are needed to "avert Armageddon."

To see how the economy works during times of stress and financial instability would ideally involve weaving financial intermediation more carefully into the existing framework, including “incentive distortions and information frictions," Bean (2009). Some of the consequences of credit inter-linkages and their policy implicationsincluding circumstances that render monetary policy ineffective- have been analysed in Stiglitz and Greenwald (2003); and Gai et al (2008) have studied systemic crises in a setting with intermediaries. But, even without intermediaries, a credit-constrained market economy — where collateral is used to handle repudiation risk — can exhibit liquidity crises and asset price crashes, Geanakoplos (2003).

How to get something big from something small: that is surely the issue. Like Krishnamurthy (2009), we focus on the amplification mechanism present in "balance sheet" models. ${ }^{2}$ For the purpose at hand - to study the dangers posed by "excessive leverage" and how capital restructuring may be needed to avert economic collapse

\footnotetext{
${ }^{1}$ Wolf (2009) comments of Koo's book: "His big point, though simple, is ignored by conventional economics: balance sheets matter."

${ }^{2} \mathrm{He}$ warns too of the onset of Knightian uncertainty in a crisis.
} 
when an asset bubble bursts - we make use of a stripped-down framework of heterogeneous agents with explicit credit constraints but no intermediaries. As an iconic representation of an economy where shocks are amplified, we turn to the model of Kiyotaki and Moore (1997) where productive Small Businesses borrow from wealth-owners with "deep pockets" who face diminishing returns. Debts are secured by collateral; but the collateral requirements generate significant externalities so aggregate shocks have persistent effects. Though the framework has noncontingent debt contracts, this approach has subsequently been extended to allow for state-dependence, Krishnamurthy (2003) and Lorenzoni (2008). ${ }^{3}$

An asset 'bubble' is included, and its collapse is the aggregate shock threatening large scale default - with assets being transferred to the less productive but "deep-pockets" agents. As this is clearly inefficient for the economy as a whole, there should be room for renegotiation of contracts. Usually this would be taken care of by the bankruptcy courts - under Chapter 11 of the bankruptcy code in the case of the U.S. But the law is essentially designed for idiosyncratic events in which assets may be disposed of at going market prices. In the face of a macroeconomic shock, a bankruptcy judge can hardly be expected to understand that what would be good for a specific case (e.g. sale of some assets), could, if generally implemented in many similar cases, trigger a collapse in prices: there will be a pecuniary externality that is not taken into account.

Since it is not obvious that "micro" bankruptcy law will offer an efficient outcome from a macro perspective, there is a case for a "super" Chapter 11 approach, to substitute for procedures usually employed in common bankruptcy law by imposing similar remedies on a macro scale, so as to internalize the externalities caused in the event of a re-sale of assets. Capital restructuring and asset purchasing facilities are discussed in this light.

Our results are consistent with the conclusion of Cúrdia and Woodford (2008) in that big interest rate cuts can, in principle, help to minimize the consequences of this type of financial shock. But there are amplification mechanisms working through balance

\footnotetext{
${ }^{3}$ Even with state-contingent contracts, however, Lorenzoni shows that the combination of debtors who must post collateral and a lack of insurance against aggregate shocks still leaves room for significant pecuniary externalities -with "inefficient" credit booms leading to excessive collateral price adjustments.
} 
sheets and asset prices that are missing from standard macroeconomic models. If the shock is big enough, interest rate policy alone will not pack enough punch to avert collapse: and the monetary authorities may be stymied by "agency" problems as intermediaries fail to intermediate.

In conclusion, official data on financial support measures undertaken in the UK and USA from 2007-2009 are briefly discussed from the balance sheet perspective taken in this paper.

\section{Asset Allocation and Pricing with Credit Constraints}

In the framework of Kiyotaki and Moore (1997), hereafter KM, heterogeneity of tastes and technology as between borrowers and lenders plays a central role. Borrowers are relatively impatient, poor, but highly productive Small Businesses who want to acquire capital assets ("land") as a factor of production"; patient wealth-owners with “deep pockets," but declining marginal productivity, are willing to finance small businesses by supplying them with short-term, roll-over funding on a fully-collateralised basis. The reason for the collateral constraint is repudiation risk: the idiosyncratic skill of small businesses entrepreneurs is noncontractible and cannot be taken over by the creditor in payment of debt. It is assumed that the fixed endowment of land is always fully employed: by whom is the issue.

Before turning to detail, we sketch the process of land acquisition by Small Businesses, or SBs, starting from an initial holding below equilibrium $\left(k_{t-1}<k^{*}\right)$.

The horizontal line in Figure 1 shows the (constant) marginal productivity of land, $\alpha$, in the SB sector while the upward-sloping line ZE indicates the "user cost" of land, its discounted productivity in the other sector ( whose holdings will be $\bar{k}-k_{t}$ ).

\footnotetext{
${ }^{4} \mathrm{KM}$ label the borrowers farmers but in the present context it seems more appropriate to think of them as Small Businesses: in the UK, for example, small and medium-sized enterprises employ more than half the workforce in the private sector.
} 


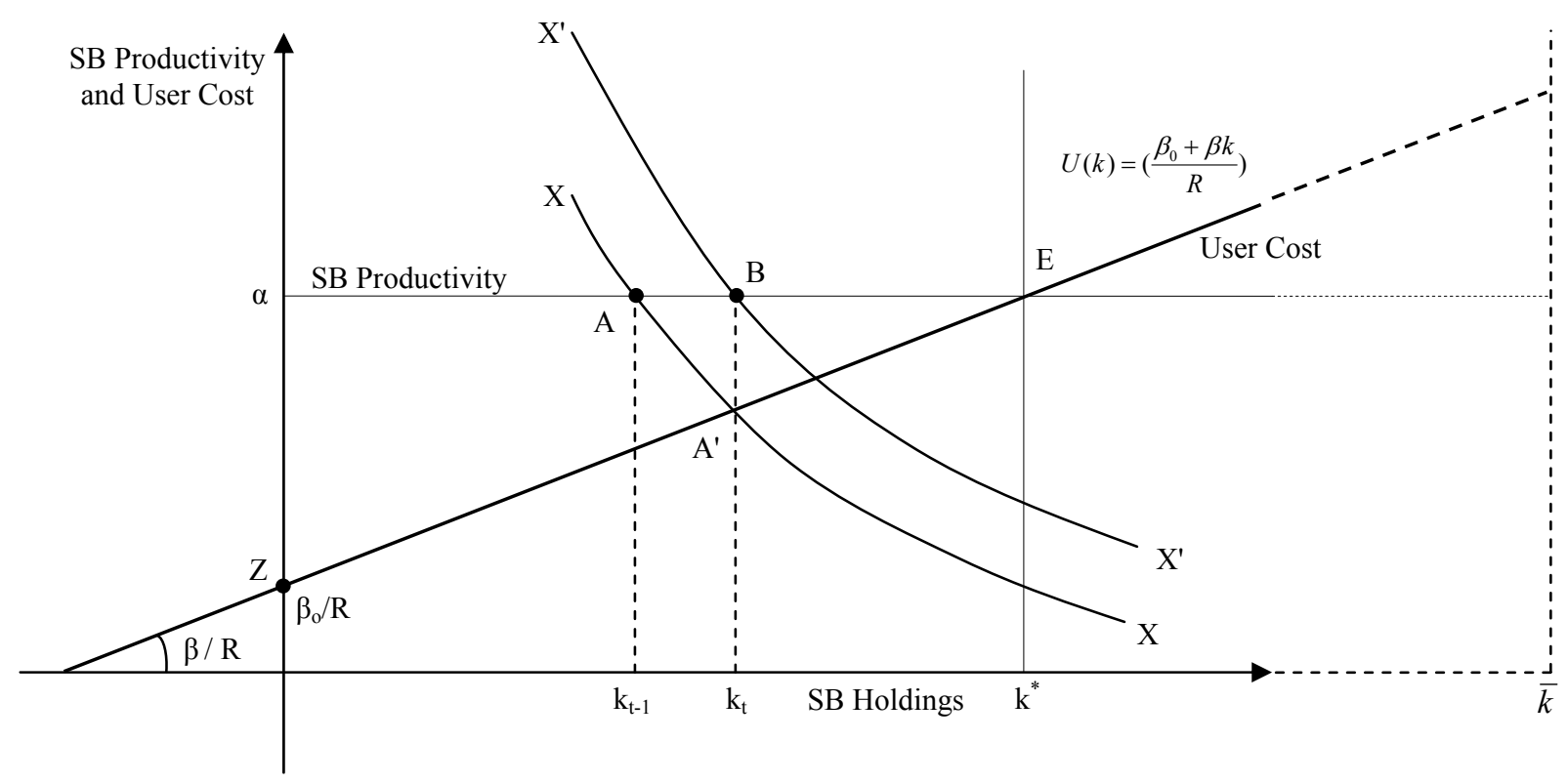

Fig.1. Not So Fast: Credit-Constrained Expansion by Small Businesses

The flow of profits accruing to the Small Businesses on initial land holdings, $\alpha k_{t-1}$, are used to expand production. As land prices reflect the lower productivity of wealth owners - and not the relatively higher productivity of small businesses — current profits (used as a down payment on borrowing to acquire more land) permit an expansion of holdings, as is shown by the hyperbola XX through A which intersects the "user cost" schedule at A'. (Land holding in periods $t+1$ can likewise be found using $\mathrm{X}^{\prime} \mathrm{X}^{\prime}$.) The fact that SB net worth, $\alpha k$, increases step-by-step as $k$ approaches $k^{*}$ from below reflects the fact that with credit rationing, there is delay in exploiting the relatively higher productivity of assets in this sector.

\subsection{The Amplification Mechanism: Micro-foundations}

Before considering what happens when an asset bubble collapses, consider how things evolve with perfect foresight, starting with Small Businesses who borrow up to the hilt and happily postpone consumption of traded goods to some later date ${ }^{5}$. Their flow of funds accounts shows land holdings, denoted $k_{t}$, evolving as:

\section{Land Accumulation $=$ Income + Net Borrowing}

\footnotetext{
${ }^{5}$ For simplicity, the production and current consumption of non-traded goods by credit-constrained agents in the original model are omitted here.
} 
or, in symbols,

$$
q_{t}\left(k_{t}-k_{t-1}\right)=\alpha k_{t-1}+b_{t}-R b_{t-1}
$$

where $b_{t}$ is the amount of one-period borrowing to be repaid as $R b_{t}$ ( $R$ is one plus the one-period interest rate), $q_{t}$ is price of land, and $\alpha$ measures the productivity of land in this sector.

Non-contractibility imposes limits on borrowing: and debt contracts secured on land are the only financial instruments that creditors can rely on ${ }^{6}$. This puts a strict upper limit on the amount of external finance that can be raised: so the rate of expansion of the Small Businesses is determined not by their inherent earning power but by their ability to acquire collateral.

The credit constraint, assumed to bind at all times, is that borrowing gross of interest matches the expected value of land, i.e.

$$
b_{t}=E_{t} q_{t+1} k_{t} / R
$$

As the degree of leverage is keyed to expectations of future prices, there will be more lending when capital gains are in prospect (as was true for sub-prime lending according to Gorton, 2008). This will be crucial when an asset bubble is considered. But with perfect foresight of future land values, substitution into (1) yields an "accumulation" equation for Small Businesses who use all their net worth to make down payments on land, namely:

ACC

$$
\left(q_{t}-q_{t+1} / R\right) k_{t}=\alpha k_{t-1}
$$

where the expression in parentheses on the left is the down-payment required to purchase a unit of land and the term on the right measures both the productivity of those resources in this sector and SB net worth. ${ }^{7}$

\footnotetext{
${ }^{6}$ Simple rental contracts are excluded because tenants may face a "hold up" problem if they add investment of their own - as KM assume later in the paper cited.

${ }^{7}$ By definition, the net worth of property companies at the beginning of date $t$ is the value of tradable output and land held from the previous period, net of debt repayment, i.e. $\left(\alpha+q_{t}\right) k_{t-1}-R b_{t-1}=\alpha k_{t-1}$.
} 
As for deep-pocket investors, they equalise expected returns from using land as a productive asset themselves and from lending (on a secured basis) at the rate of interest $\mathrm{R}$, so

$\mathrm{ARB}$

$$
f^{\prime}\left(k_{t}\right)+E_{t} q_{t+1}-q_{t}=(R-1) q_{t}
$$

where $f^{\prime}\left(k_{t}\right)$ is the marginal productivity of land in the unconstrained sector (expressed as a function of $k_{t}$ the amount of land in the constrained sector as in Figure 1 above, assuming the total amount of land is fixed ${ }^{8}$ ).

This arbitrage condition can be rewritten to show how the "down payment" by the borrower has to match the "user cost" of land:

$$
q_{t}-q_{t+1} / R=f^{\prime}\left(k_{t}\right) / R=u\left(k_{t}\right)
$$

where $u\left(k_{t}\right)$ is the discounted marginal productivity of land for deep-pocketed investors (where there is also a one period lag in production).

The simple dynamics of asset accumulation by small businesses indicated in Figure 1 comes from substituting (5) into (3) to give:

$$
u\left(k_{t}\right) k_{t}=\alpha k_{t-1}
$$

where the absence of asset prices in (6) reflects the assumption of perfect foresight.

For analytical simplicity, assume (as in Figure 1) that the "user cost" of land for Small Businesses is linearly related to their collective holdings $k_{t}$, so:

\footnotetext{
${ }^{8}$ Note that, with fixed total endowment $\bar{k}$ and diminishing returns in production in the unconstrained sector where output is $g\left(\bar{k}-k_{t}\right)$, defining $f^{\prime}\left(k_{t}\right)=g^{\prime}\left(\bar{k}-k_{t}\right)$ implies that $f^{\prime \prime}=-g^{\prime \prime}>0$ i.e. Small Businesses face a rising cost of acquiring land.
} 


$$
u\left(k_{t}\right)=\left(\beta_{0}+\beta k_{t}\right) / R
$$

where $\beta$ corresponds to the second derivative of the production function in the unconstrained sector, i.e. measures the rate of decline in the marginal productivity of land used by deep pocket investors, and the discount factor $1 / \mathrm{R}$ reflects a one-period lag in production. As for the price of land, this is determined by deep pocket investors as the present discounted value of their own "user cost," i.e.

$$
q_{t}=\sum_{s=0}^{\infty} u\left(k_{t+s}\right) / R^{s}
$$

where this is measured along the path towards equilibrium.

\subsection{Amplification and Persistence: Macro-Dynamics}

To summarize, with current profits used to pay the user cost, asset allocation and prices in the absence of shocks evolve as follows:

ACC

$$
\left(\beta_{0}+\beta k_{t+1}\right) k_{t+1} / R=\alpha k_{t}
$$

ARB

$$
q_{t+1}=R q_{t}-\left(\beta_{0}+\beta k_{t}\right) .
$$

The recursive structure - so it seems that land prices do not affect the process of acquisition - depends crucially on the assumption of perfect foresight, however. Accumulation will be affected by "errors of forecast" in prices, as we see presently. The accumulation process has two points of stationarity. There is a stable equilibrium, $k^{*}=\left(R \alpha-\beta_{0}\right) / \beta, q^{*}=\left(\beta_{0}+\beta k^{*}\right) /(R-1)$, where land is allocated efficiently in terms of its productivity. There is another, inefficient and unstable, equilibrium, $k^{*}=0$, $q^{*}=\beta_{0} /(R-1)$, where credit-constrained Small Businesses have lost all their property. A key issue is whether there are forces which might throw the system into the inefficient equilibrium, at least for a while. 
For convenience, the system may be linearised around the stable equilibrium so:

$$
\left[\begin{array}{c}
k_{t+1}^{0} \\
q_{t+1}^{0}
\end{array}\right]=\left[\begin{array}{l}
\lambda \ldots .0 \\
-\beta \ldots R
\end{array}\right]\left[\begin{array}{l}
k_{t}^{0} \\
q_{t}^{0}
\end{array}\right]
$$

where $\lambda=\frac{R \alpha}{\beta_{0}+2 \beta k^{*}}<1 \quad$ is the stable root and the variables are measured from equilibrium ( so $k_{t}^{0}=k_{t}-k^{*}$ ). The dynamics of adjustment on the path to equilibrium will lie on the path shown schematically as SS in Figure 2, where actual outturns will be discrete points because of the discrete time formulation.

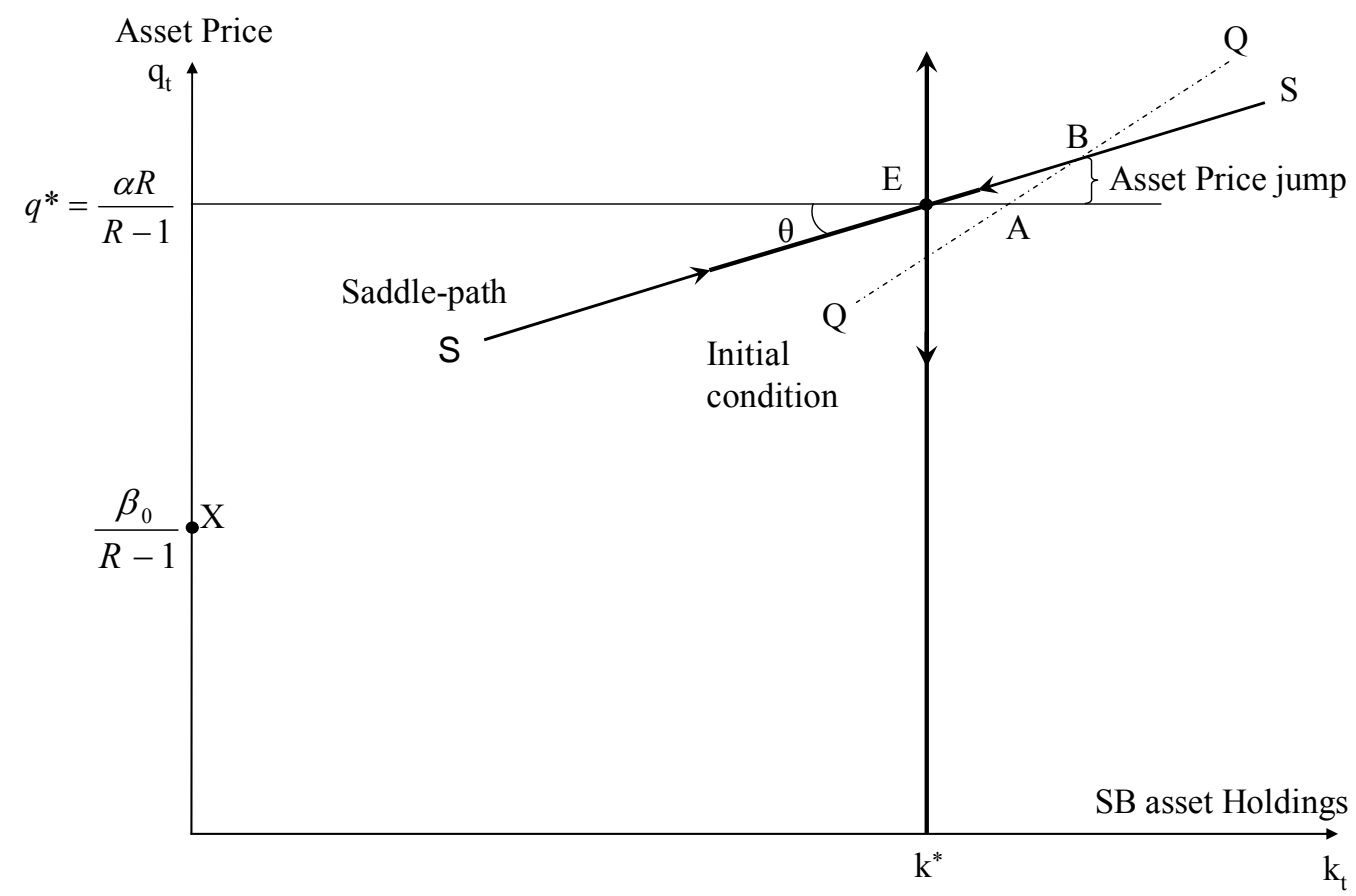

Fig. 2. Stable Convergence: Amplified Shocks

The unstable eigenvector is vertical: but the slope of the stable path, effectively a weighted average of productivity in the two sectors, is

$\theta=\frac{\beta}{R-\lambda}>0$

The parameter $\theta$ measures the sensitivity of land prices to fully anticipated transfers 
of ownership between the two sectors: but what if there is an aggregate shock?

Assuming the system is in equilibrium at $\mathrm{E}$, the immediate effect of a technology shock ( in the form of a temporary increase in productivity for all Small Businesses) is shown in Figure 2 by the intersection of the "initial condition" QQ, specified algebraically below, with the stable path SS. As the figure suggests, the impact on land allocation has two components. The distance EA, measured horizontally from equilibrium to the initial condition QQ, indicates how far Small Businesses could expand at a constant land price, as they go on the acquisition trail using the extra profits as down-payment on fresh borrowing. Because all businesses are doing the same, however, the price of land will increase, raising borrower net worth and allowing for more acquisitions. This is the "financial accelerator" that takes short-run equilibrium from point A to point B on SS. From there, in the absence of fresh shocks, the system will gradually return to equilibrium along the stable path.

\subsection{The Initial Condition - the Acquisition Schedule}

To take account of the positive productivity shock, Small Business net worth in equation (8) must be corrected for the "error of forecast." So, at the time of the shock, $k_{t}$ and $q_{t}$ must satisfy

$\left(\beta_{0}+\beta k_{t}\right) k_{t} / R=\left[\alpha+\Delta+\left(q_{t}-q^{*}\right)\right] k^{*}$

where $\Delta$ is the common productivity shock. On the left is the opportunity cost of land $k_{t}$ used by SBs ( the "user cost" times quantity held): on the right the "corrected" net worth of the Small Businesses in aggregate.

Given the linearization, this initial condition can be recast as

$$
\left(\beta_{0}+2 \beta k^{*}\right) k_{t}^{0} / R=(\alpha / \lambda) k_{t}^{0}=\left(\Delta+q_{t}^{0}\right) k^{*}
$$

where the variables are now measured from equilibrium and the term $q_{t}^{0} k^{*}$ indicates the presence of a "financial accelerator." This implies that 
$k_{t}^{0}=\left(\Delta+q_{t}^{0}\right) c$

where $c=k^{*} \lambda / \alpha$, which is the upward-sloping schedule QQ in Figure 2-the "acquisition schedule" of highly-levered players unexpectedly flush with fresh funds.

\section{A Bursting Bubble, De-leveraging and Potential Collapse}

\subsection{Asset Bubbles}

While the Real Business Cycle literature is concerned with technology shocks, our focus - like Koo (2008) in his account of the Japanese experience - is on aggregate financial shocks, a negative asset-price correction in particular. Instead of unanticipated profits triggering acquisitions, balance sheet write-downs will trigger liquidation.

How plausible is it to postulate a large, collective error of forecast of this kind? Standard neoclassical theory precludes the existence of bubbles: so does the efficient markets hypothesis. As Abreu and Brunnermeier (2003) demonstrate, however, the backwards induction argument typically used to rule out bubbles fails if people disagree. Lack of common knowledge — in the form, say, of dispersed beliefs about when a bubble will end — can be sufficient to generate its persistence.

To account for the existence of the bubble in US house prices that peaked in 2006, Robert Shiller (2008, p. 62) took a behavioural perspective-observing that people "try to think of speculative events as rational responses to information... [and] accept as simple fact the stories that accompany the bubble." So, too, did Laibson (2009), in his Hahn Lecture to the Royal Economic Society — with extrapolation of beliefs and trend-chasing, wishful-thinking and over-confidence, plus the phenomenon of socalled "social proof," all cited as relevant factors.

Inflated asset prices can often be rationalised by plausible stories of anticipated fundamentals. Say, in the current context, there is news of a potential technological improvement for Small Businesses which promises higher productivity (i.e. higher $\alpha$ ) and a greater share of resources for that sector. With the expectation of widespread 
implementation at a later time $\mathrm{T}$, the asset price should jump on the news, with land allocation shifting from $\mathrm{E}$ to $\mathrm{A}$ on the acquisition schedule QQ, and increase steadily thereafter towards the higher value stable path $\mathrm{S}^{\prime} \mathrm{S}^{\prime}$ associated with the $\alpha^{\prime}>\alpha$ along the integral curve shown in Figure 3. But what if, when the asset price has reached B at time T-1 and all Small Businesses are set for expansion next period, the promised implementation fails to occur?

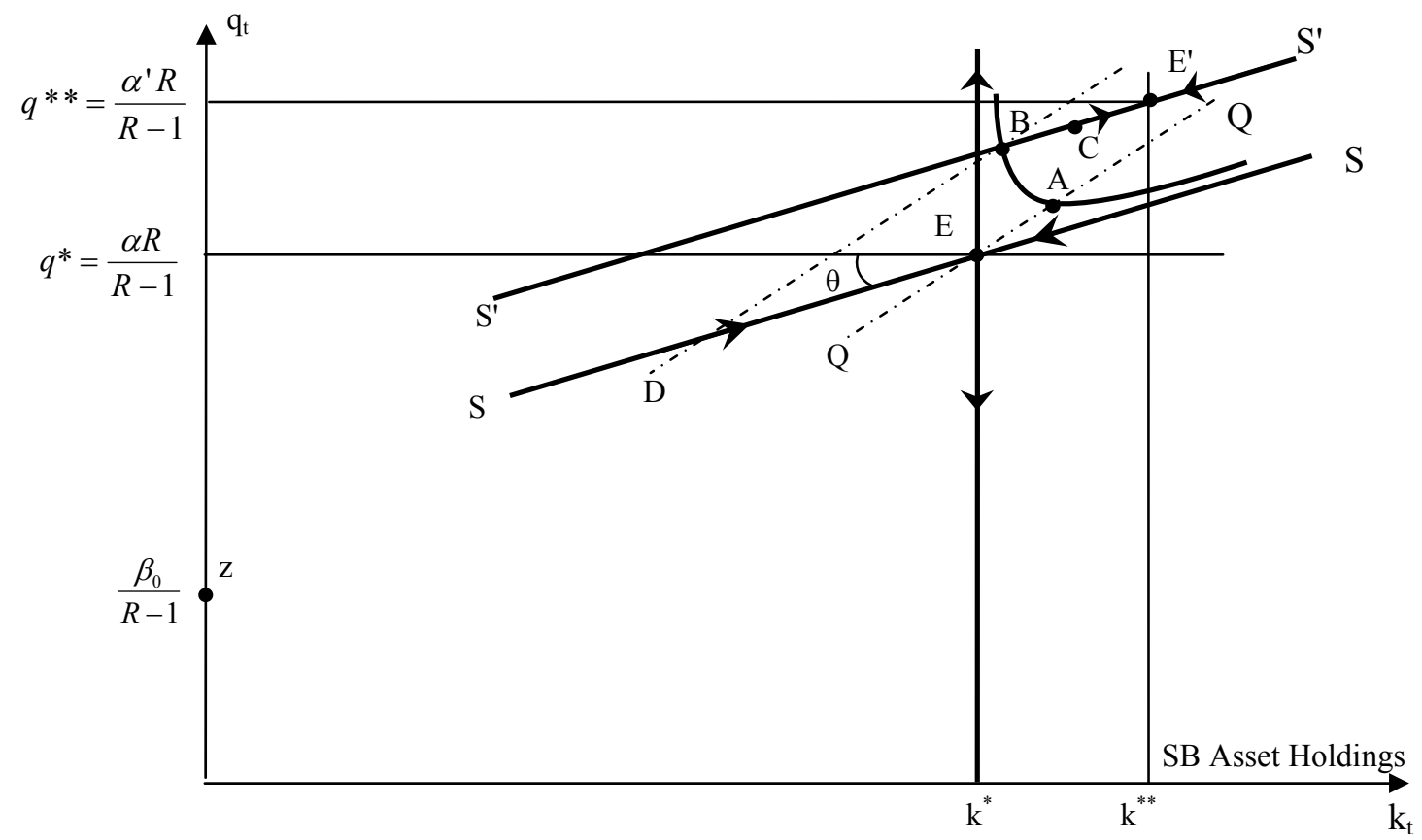

Fig. 3. False Dawn: a Bubble as Collective Illusion

There will be a nasty shock common to Small Businesses as asset prices fall and their balance sheets are marked-to-market: they have, by assumption, been borrowing the discounted value of land one period ahead, and will be loaded-up with debt without the anticipated flow of income needed to service it. Liquidation not acquisition will now be their mantra as they try to pay down their debts. ${ }^{9}$ The "fire-sales" will add to the downward pressure on land prices as the financial accelerator goes into reverse. There will, effectively, be an increased demand for liquidity (as suggested by the "disposal schedule" DD drawn through B in the Figure and discussed further below). The asset price correction may well "overshoot": could it lead to widespread insolvency?

\footnotetext{
${ }^{9}$ So long as the shock comes after they have put in their labour and committed their net worth, small businesses cannot unilaterally bargain a debt write-down: so - like US farmers in the Great Depression they will try to sell assets to "pay down" their debts.
} 


\section{2 "Firesales" and the Prospect of Insolvency}

For analytical convenience, consider the canonical case of price overvaluation when land holdings are at $\mathrm{k}^{*}$, i.e. the bubble path is the unstable eigenvector that passes vertically through $\mathrm{E}$; and the size of the bubble is measured by the excess above of $\mathrm{E}$ of points at points such as B or B'. At equilibrium, E, all revenues are used to pay interest on debt; so interest payments on the bubble path are partly covered by fresh borrowing, as in a Ponzi scheme. ${ }^{10}$ The ending of the bubble will clearly pose a liquidity problem and may threaten insolvency, as indicated in Figure 4 by the initial conditions, labelled DD, D'D' (for bubbles of different size), assuming perfect foresight prevails after the bubble bursts.

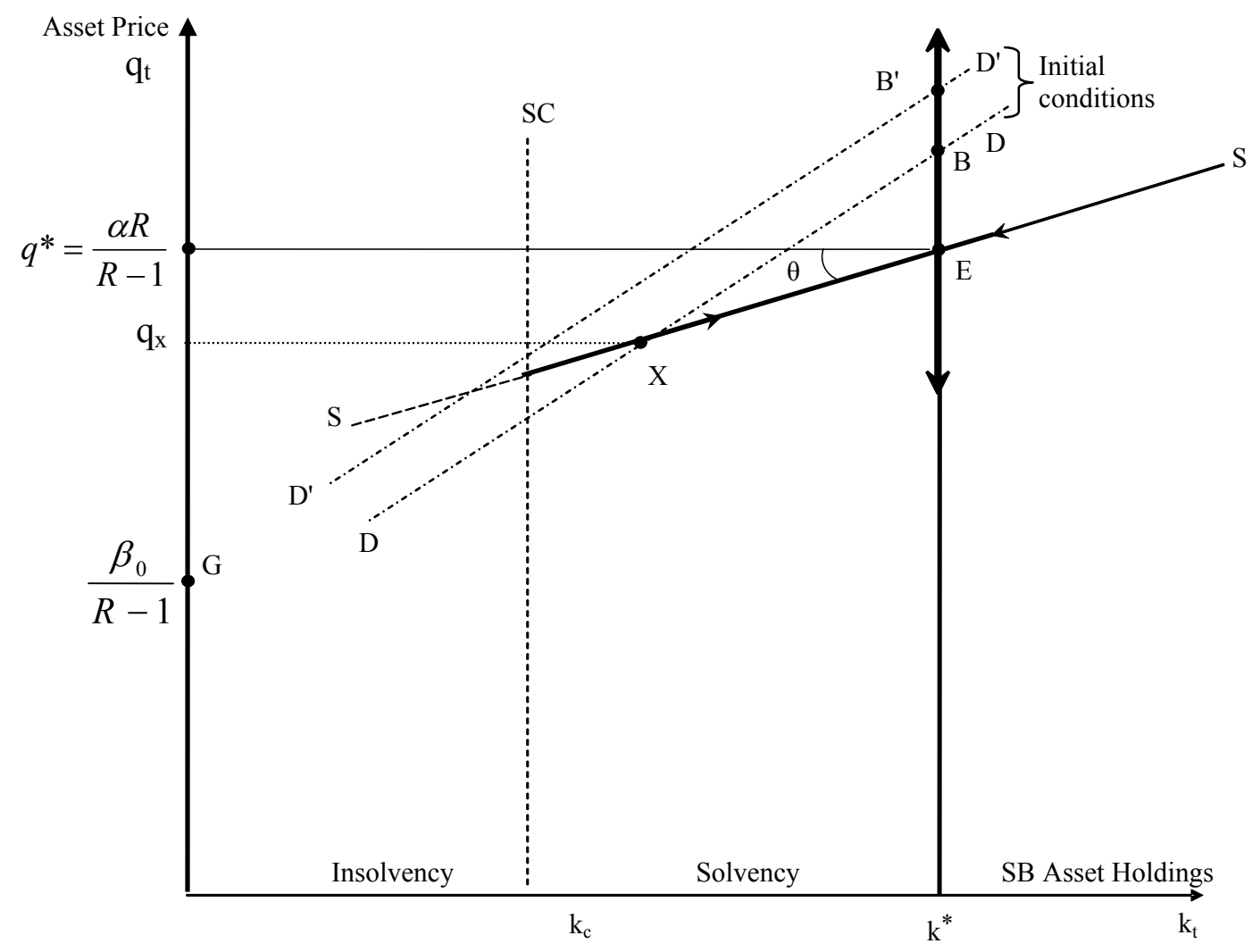

Fig. 4. Aftermath of an Asset Bubble

${ }^{10}$ At E itself, $r b^{*} k^{*}=\frac{r q^{*} k^{*}}{R}=\frac{r \alpha k^{*} R}{(1-R) R}=\alpha k^{*}$; above E, where $q>q^{*}$, interest charges exceed current revenue. 
How are these initial conditions defined? Allowing for an adverse price shock again involves correcting the net worth in equation (8) for the error of forecast, so $k_{t}$ and $q_{t}$ are implicitly defined by

$\left(\beta_{0}+\beta k_{t}\right) k_{t} / R=\left[\alpha-\left(q^{b}-q_{t}\right)\right] k^{*}=\left[\alpha-\left(q^{b}-q^{*}\right)-\left(q^{*}-q_{t}\right)\right] k^{*}$

together with pricing equation (11) above. Given the linearization, this initial condition can be rewritten as

$\left(\beta_{0}+2 \beta k^{*}\right) k_{t}^{0} / R=(\alpha / \lambda) k_{t}^{0}=\left(-\left(q^{b}-q^{*}\right)+q_{t}^{0}\right) k^{*}=\left(-\Delta+\theta k_{t}^{0}\right) k^{*}$

where $\left(q^{b}-q^{*}\right) k=\Delta$ is the absolute size of the net worth correction for "excess borrowing" and $q_{t}^{0} k^{*}=\theta k_{t}^{0} k^{*}$ is the "financial accelerator" due to fire-sales that this induces. Defining $c=k * \lambda / \alpha$ as before, this can be written as $k_{t}^{0}=\left(-\Delta+q_{t}^{0}\right) c$

defining the "disposal" schedules shown DD, D'D' in Figure 4.

These schedules for asset disposal by Small Businesses can be interpreted as an unexpected need for liquidity on their part, Krishnamurthy (2009). From this perspective, asset prices have to fall until the balance-sheet-driven "demand for liquidity" by Small Businesses (measured to the left from $\mathrm{k}^{*}$ to DD, for example) is matched by the "supply of liquidity" by the residual buyers of land who have no balance sheet problems (the agents with "deep pockets") whose take-up of land is measured from $\mathrm{k} *$ to SS.

In his discussion of amplification through balance sheets and asset prices, Krishnamurthy assumes that the "overshooting" will not be severe enough to render the illiquid agents insolvent: so equilibrium might be reached at a point such as $\mathrm{X}$, with asset price such as $q_{X}$, where prompt de-leveraging permits stable convergence back to E. According to Koo $(2008$, p. 14,15), however, de-leveraging made many firms technically insolvent in Japan after the bubble burst, a situation which we can 
represent by the disposal schedule D'D' (associated with the collapse of a larger asset bubble) which fails to intersect SS to the right of SC, the Solvency Constraint.

\subsection{The Solvency Constraint}

How this constraint may be determined can be seen with reference to Figure 5, where each side of equation (16) is plotted separately, using the version linearised around equilibrium, so the opportunity cost of land $\left(\beta_{0}+2 \beta k^{*}\right) k_{t}^{0} / R$ is shown as OO .

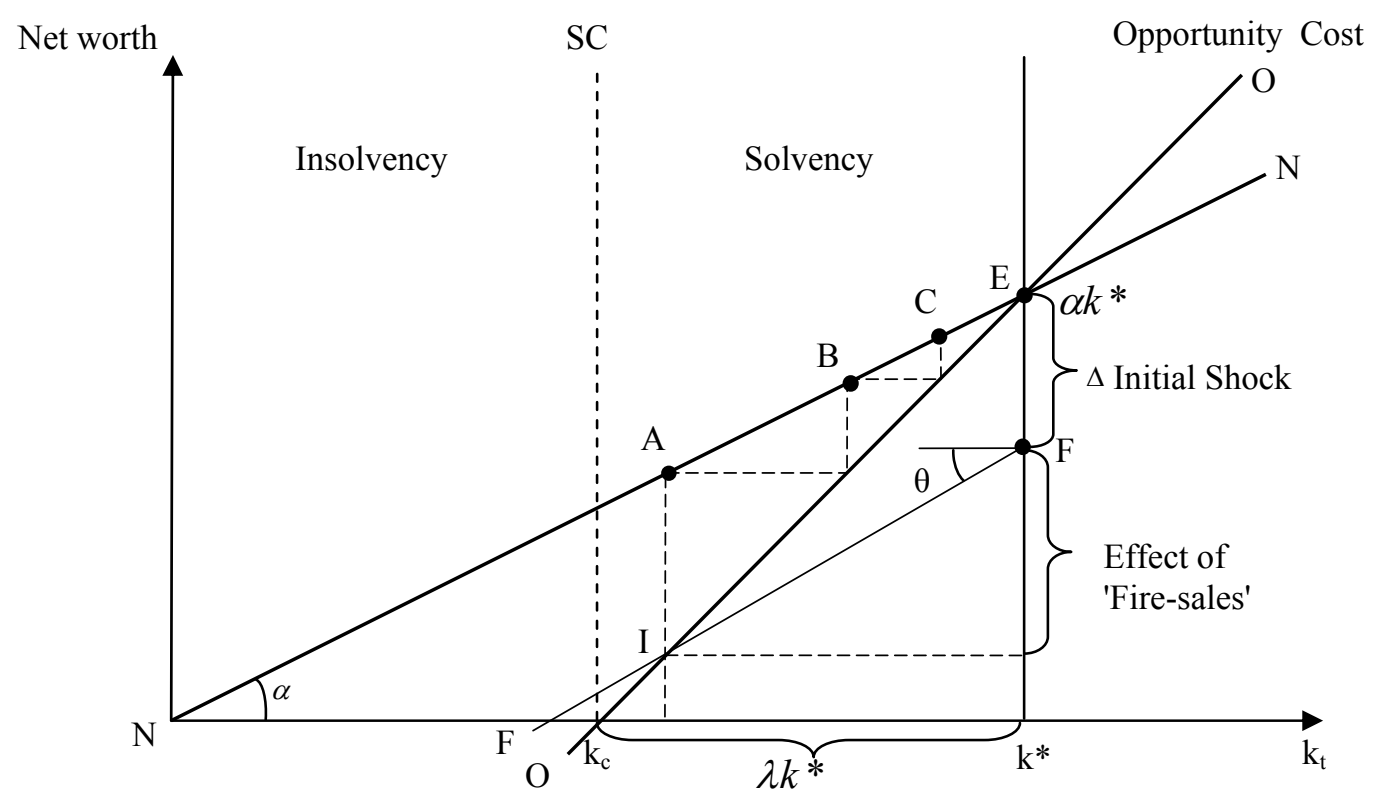

Fig. 5 Net Worth, "Fire-sales" and the Prospect of Widespread Insolvency

In the absence of shocks, the aggregate net worth of credit-constrained businesses will lie on the line NN passing through the origin with slope $\alpha$ (with the steps A,B,C, converging to equilibrium at $\mathrm{E}$ with net worth of $\alpha k^{*}$ as described earlier with reference to Fig. 1). Where land holdings of $\mathrm{k}^{*}$ have become overvalued, however, an asset price correction will reduce net worth, as debt contracted beforehand exceeds the value of the collateral assets at the equilibrium price. This adverse balance sheet effect is shown by $\Delta$, the distance EF in the figure. But net worth will also be reduced by asset price "overshooting" due to fire-sales. The schedule incorporating both these effects is 
shown as $\mathrm{FF}^{11}$ with slope $\theta$, where the "overshooting" term is given by the approximation $\left(q_{t}-q^{*}\right)=\theta\left(k_{t}-k^{*}\right)$. The point $k_{C}=\lambda k^{*}$, where fire-sales have reduced net worth to zero, identifies the Solvency Constraint, labelled SC here and in Fig. 4. As this would imply losses of $\theta \lambda k^{*}$ due to fire-sales, it implies that $\Delta=(\alpha-\lambda \theta) k^{*}$ is the largest financial hit consistent with the solvency of small business enterprise without intervention. ${ }^{12}$

In fact, highly leveraged borrowers can very easily become insolvent. If their net worth were only $5 \%$ of assets held as collateral for loans, a correction of asset prices in excess of this would be enough to wipe out their net worth - even before fire-sales begin. (The system becomes a good deal more robust, however, when borrowers are subject to a prudential margin requirement which provides an ex ante buffer against such losses, Edison et al (2000), Gai et al (2008): with "dynamic provisioning," the shock to net worth will be cushioned by this buffer. ${ }^{13}$ )

As Koo describes it, the collapse of an economy-wide asset bubble could be the economic equivalent of the collapse of a supernova - with the "black hole" of insolvency threatening to swallow whole sectors of an over-leveraged economy. The consequences of technical insolvency were seen as so severe, ${ }^{14}$ indeed, that a preemptive strategy of concealing the true balance sheet position was apparently widespread in Japan. ${ }^{15}$

\footnotetext{
${ }^{11}$ That the net worth function FF slopes downward to the left in the figure shows how the volume of firesales drives down the price.

${ }^{12}$ Note that, for $\beta_{0}>0$, the "user cost" will always be non-negative, so the linearity of the schedule $\mathrm{OO}$ in the Figure is potentially misleading. Without linearizing, the maximum sustainable aggregate shock can be found as a limiting point of intersection between the net worth schedule FF and the (non-linear) opportunity cost schedule, as in Edison et al (2000)

${ }^{13}$ If, for example, prudential margin requirements are suspended after the shock - leaving only the down-payments as described above - the initial equilibrium for $k_{t}$ may be found as before, except that the shock $\Delta$ will be net of the prudential margin held beforehand. Silonov (2008) looks at dynamic margins in this context.

14 "If it becomes known that a borrower is technically insolvent, loans extended to the company will become bad loans and the lender will be forced by government regulators to cut off credit, and try to collect on existing loans." Koo (2008,p.44)

15 "Only the executives who borrowed the money and the bankers who lent it truly understand the problem. But since neither will ever reveal this information to outsiders, external observers remain wholly oblivious to the situation." Koo (2008,p.45)
} 


\section{Averting the Threat of Mass Insolvency}

Wholesale reallocation of assets to relatively unproductive, "deep pocket" lenders would obviously be socially inefficient. What can be done to avert it (assuming assets are marked-to-market, so concealment is not an option)? One way is through a cut in interest rates that, if big enough, and if the situation is not dire enough, would boost asset prices and guarantee that the net-worth of borrowers does not fall too much, guaranteeing an equilibrium without outright default, even if at very discounted asset prices. Another way is through an explicit capital restructuring in which leverage is reduced, either by capital injections, debt-equity swaps, or simple debt forgiveness. The problem of capital restructuring is that the presence of externalities implies the need for some macro-agency (essentially some governmentsponsored institution) that would consolidate the troubled businesses and decide simultaneously (and this is the key) how all of them would be resolved in a common procedure, whether through capital injections by this agency or agency-sponsored debt-equity swaps. The key is that some agency should resolve most problems in a single take, to internalize the re-sale consequences of individual cases. As it not only has to be big enough but also to have greater powers of enforcement than private creditors, that probably calls for the hand of the government. A third way is for the government to purchase the assets themselves, supplying liquidity to prevent asset prices from collapsing. We consider these actions, starting with asset purchase.

\subsection{Asset Purchase by Government Agencies}

Agencies of government can check the collapse of asset prices by acting as "buyer of last resort." (Figure 4 shows how buying at a floor price of $q_{X}$ will prevent insolvency after a bubble bursts at B', for example.) The authorities effectively augment the supply of liquidity so that de-leveraging can take place without causing insolvency. This was, it seems, the idea behind the original Paulson plan in the U.S.. 


\subsection{Capital Restructuring: Chapter 11 Procedures}

When the "going concern" value of small businesses after restructuring exceeds the alternative "user cost," the principles of bankruptcy law confirm that they should be kept going; and in the U.S. for example Chapter 11 of the bankruptcy code aims at restructuring the balance sheet so as to avoid premature liquidation. The customary legal procedures are, however, designed to handle small, idiosyncratic shocks - not macro shocks hitting the whole economy. Judges can hardly be expected to take account of externalities imposed by "fire-sales" of the assets involved in individual cases, making outright liquidation much more likely.

Internalising the price effects of asset "fire-sales" in the midst of a crisis requires an override of normal restructuring procedures - what we refer to as "super" Chapter 11 actions, where the principles of bankruptcy are applied at a macro level. Three kinds of restructuring are considered in broad outline: a debt-equity swap, a temporary capital injection, and a debt write-down. How these might work in practice - at least for banks — has been vividly demonstrated in the recent restructuring of bank balance sheets in the U.K. and U.S., see Table 1 below.

\section{(A) Debt-Equity Swap}

Capital restructuring under Chapter 11 frequently involves an exchange of debt for an equity share, so lenders become owners, relieving the borrower of collateral requirements and interest payment obligations, Zingales (2008). In Figure 5, for example, the excess debt EF owed to the wealth owner could be swapped for equity of the same value. (To avoid the moral hazard problem of equity ownership in the KM framework, however, an agency taking up such ownership rights would need ways of enforcing payment beyond those available to private creditors.)

(B) Capital Injection

A key element of the financial support for the U.K. financial sector has been the provision of capital injections in preference shares or unsecured debt. How can this 
avoid a meltdown if it is designed to be temporary? The answer, broadly speaking, is by checking the de-leveraging process that follows a shock to net worth, and so limiting the negative externality of asset sales.

In terms of the canonical model we use, let deep-pocket lenders provide unsecured financing $\Gamma$ when the shock occurs, to be repaid as $\mathrm{R} \Gamma$ one period later, where $\mathrm{R}$ is the gross market rate of interest. (To avoid the moral hazard problem of unsecured lending, assume also that the capital injection is arranged through the agency of the government, which has ways of enforcing payment beyond those available to private creditors.)

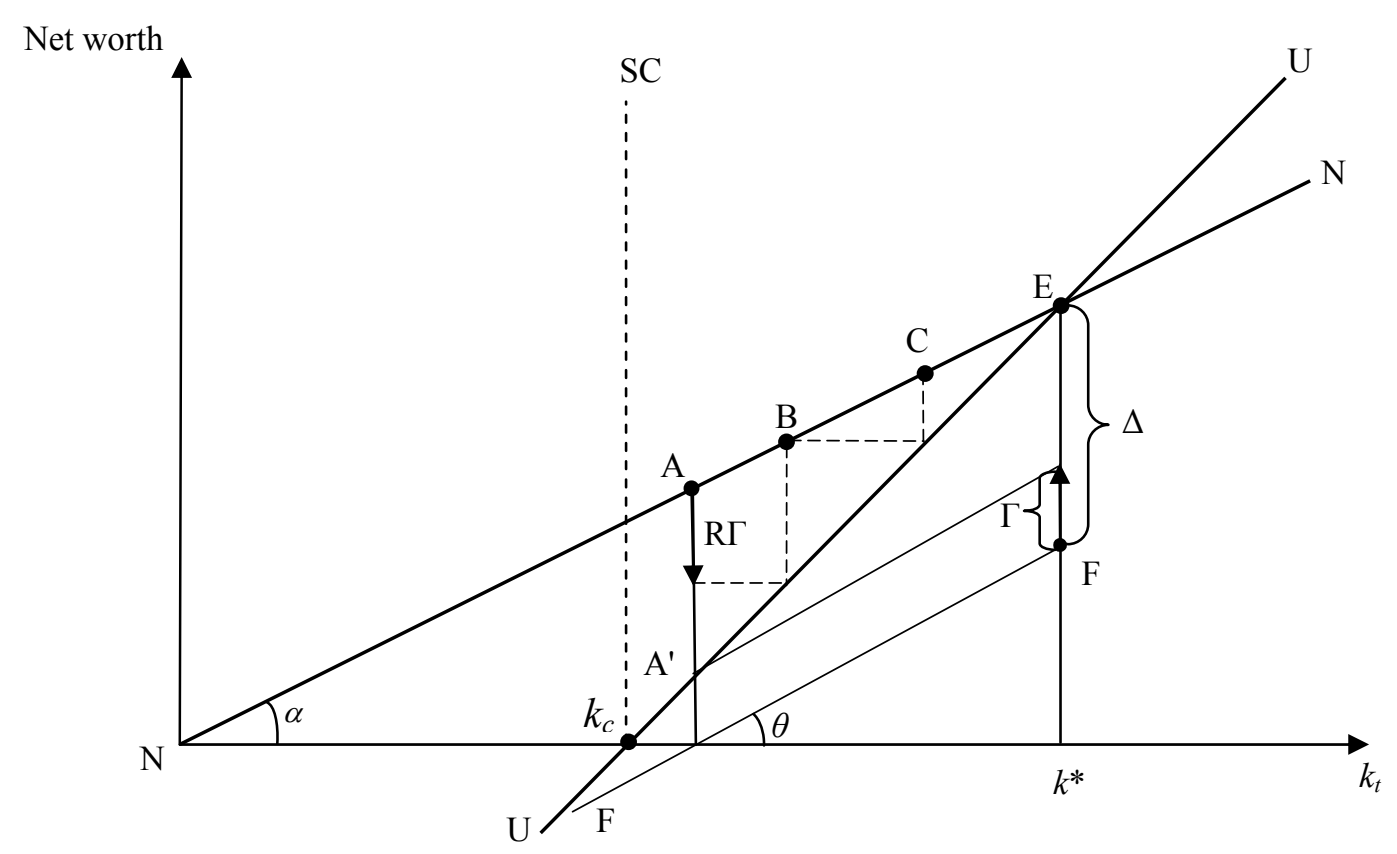

Fig. 6. A Capital Injection to "Avert Armageddon"

This extra capital will shift the financing constraint up from FF, as shown in Fig. 6, giving first-period equilibrium at $\mathrm{A}^{\prime}$ and so avoiding insolvency. By providing financial support to indigent Small Businesses in this way, their immediate need for liquidity has been reduced, as Krishnamurthy (2009) puts it, so the fire-sales equilibrium is less dire. (The disposal schedule shown as D'D' in Figure 4 will be shifted downwards, checking the fall in prices.) Some of the capital injections provided to the financial sector have, in fact, been repaid fairly promptly on both 
sides of the Atlantic. Figure 6 illustrates a special case where borrowers are able to repay the temporary finance with interest in the very next period ${ }^{16}$.

\section{(C) Loan Write-Downs}

What about debt forgiveness? A loan write-down is another way of avoiding the negative externalities caused by loan enforcement programmes. As Stiglitz (2008) has argued:

We need bankruptcy reform allowing for homeowners to write down the value of their homes and stay in their houses, in addition to the help that the current legislation proposes. [Furthermore], the government could assume part of the mortgage, taking advantage of the lower interest rate at which it has access to funds and its greater ability to demand repayment. In return for the lower interest rate- which would make housing more affordable - it could demand from the homeowner the conversion of the loan into a recourse loan (reducing the likelihood of default), and from the original holders of the mortgage, a write down of the value of the mortgage to say $90 \%$ of the current market price.

\subsection{Monetary Policy: Emergency Rate Cuts}

Cúrdia and Woodford (2008) recommend a prompt cut in policy rates to offset financial frictions, and the model we use confirms that reducing the real interest rate when a bubble bursts — and for a while thereafter ${ }^{17}$ — should, in principle, help to limit the fire-sales at the root of the crisis. But how reliable is this remedy?

The positive potential of cutting the interest rate is illustrated in Figure 7, where the threat of insolvency posed by a bursting bubble is headed off and the system recovers, as shown by the path labelled $\mathrm{B}, \mathrm{A}, \mathrm{A}_{\mathrm{T}}, \mathrm{E}$. (Note that the figure now includes the stable path (S'S') and equilibrium (E') associated with a permanently lower level of interest rates $\left(\mathrm{R}^{\prime}<\mathrm{R}\right)$; and an integral curve II associated with this equilibrium.).

\footnotetext{
${ }^{16}$ Repayment will of course slow down the rate of acquisition, as shown in the figure.

${ }^{17}$ Quite a long time, if Japanese experience is any guide.
} 


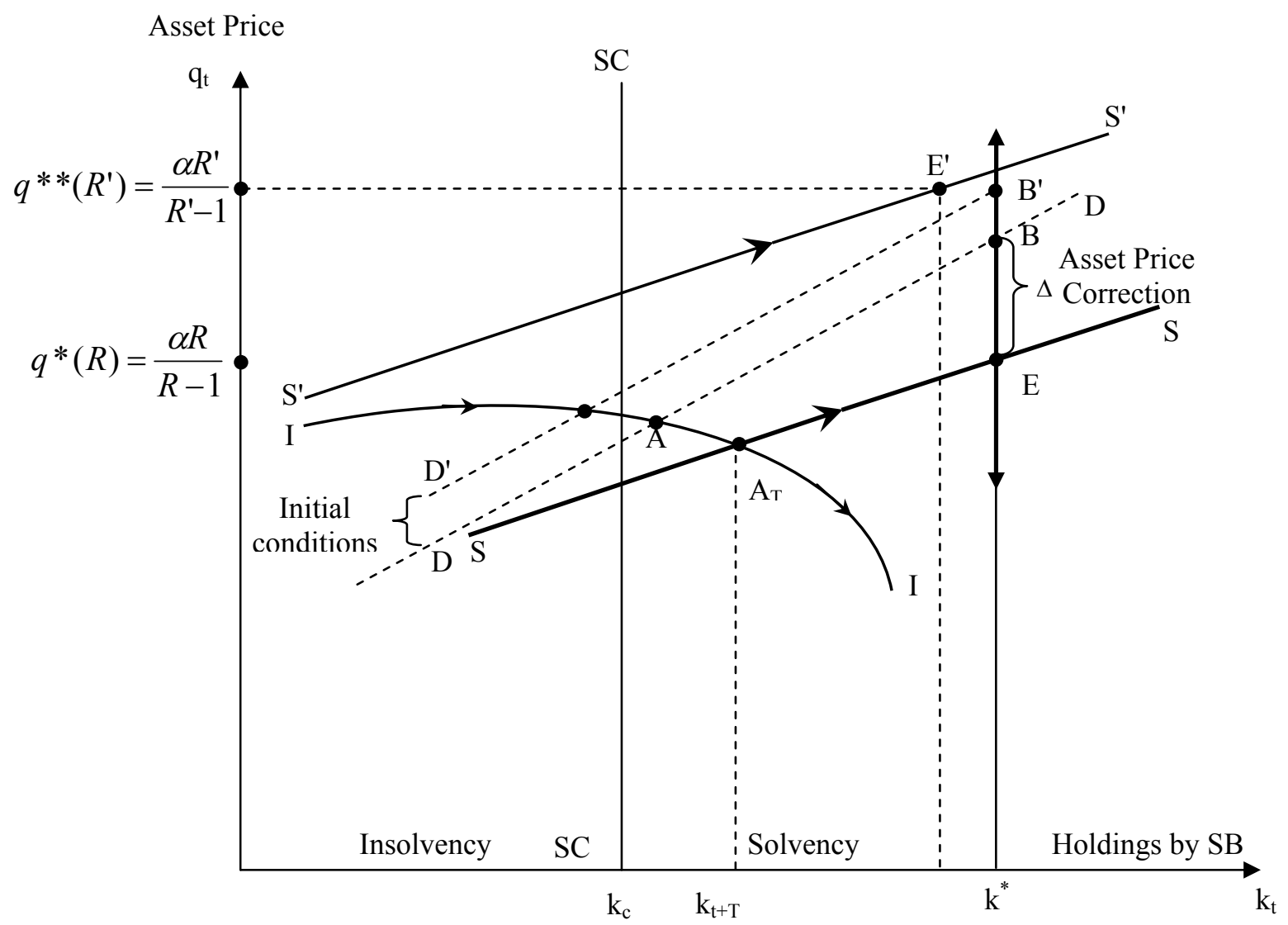

Fig. 7. Cheap Credit Can Help

By construction, the lowering of the interest rates to $\mathrm{R}^{\prime}$ for $\mathrm{T}$ periods after the bubble bursts at B should prevent insolvency, with initial equilibrium at point $\mathrm{A}$ : and return to equilibrium will be achieved providing it takes $\mathrm{T}$ periods to travel from $\mathrm{A}$ to $\mathrm{A}_{T}$ i.e. to travel along the integral curve II from its intersection with the disposal schedule DD to its intersection with the stable path SS. (But if the bubble was larger, at point $\mathrm{B}^{\prime}$ for example, this would not avert insolvency: a longer duration or a deeper cut of the interest rate would be called for.)

Though the analysis seems to provide substantial support for Cúrdia and Woodford (2008), the efficacy of rate cuts is hobbled by two factors. ${ }^{18}$ First, of course, due to the zero-bound on nominal rates, there is only so-much cutting that the Central bank

\footnotetext{
${ }^{18}$ For emerging markets, where dollarised debts are a potent source of balance sheet shocks, cutting interest rates in a crisis is usually not an option for external reasons - strengthening the case for Chap 11-style restructuring procedures, both domestically, Furman and Stiglitz (1998), Miller and Stiglitz (1999) and internationally, Stiglitz (2006, Chap 7).
} 
can do! Second — and just as important — the benefit of crisis cuts in policy rates may not be passed on to Small Businesses.

In an environment with intermediaries, "agency problems" can easily arise ${ }^{19}$ : and the easing of monetary policy in a crisis may well be offset by an increase in risk aversion by banks. If banks retain the benefits for themselves - increasing their margins so as to recapitalise, for example - then, as Stiglitz and Greenwald (2003, pp. 126-128) point out, the easing of policy rates will be like pushing on a string.

The optimistic results attributed to rate cuts come with an important caveat: that monetary economics without banking is like the Macbeth's banquet without the ghost of Banquo!

\section{Conclusion}

By adding an asset bubble to a canonical model of highly leveraged businesses, we have highlighted the vicious downward spiral that may develop when asset prices begin to fall and have outlined a variety of measures that may be used to check this with the government stepping in because of the externalities and moral hazard involved. Emergency action to restore and restructure balance sheets is not unusual in emerging markets facing financial crisis, in Thailand for instance ${ }^{20}$, and in Argentina (where dollar bank loans of Small Businesses were "pesified" by law soon after the peso collapsed in early 2002). But it stands in sharp contrast to the view from conventional models - that "the effects of a worsening of financial intermediation are likely to be limited" and can be handled by interest rate cuts alone.

Besides cutting interest rates as far as they can, the authorities in both the US and UK have of course undertaken extraordinary financial interventions, amounting in total to around three quarters of GDP - interventions that have more than doubled the size of central bank balance sheets - as shown in Table 1.

\footnotetext{
${ }^{19}$ As discussed in Hellman et al (2000), for example.

${ }^{20}$ As discussed in Edison et al (2000).
} 
Table 1. Size of financial system support measures

Trillions (local currencies)

Available central bank support

\begin{tabular}{|c|c|}
\hline United Kingdom & United States \\
\hline Jan. Latest & Jan. La \\
\hline
\end{tabular}

Current direct lending to

financial institutions

$0.05 \quad 0.10$

$0.04 \quad 0.44$

Asset purchases and other

loans

$-\quad 0.15$

Collateral swaps

$-\quad 0.19$

0.20

Central bank currency

swap lines

- No limit

- No limit

\section{Available government support}

Guarantees of financial

institutions' liabilities

Insurance of financial assets

$-\quad 0.37$

$-\quad 2.08$

$-\quad 0.46$

Capital injections to banks and

special purpose vehicles

$-0.06$

$-\quad 0.70$

Increase in public sector support

$-\quad 1.26$

$-\quad 10.44$

Memo: US dollar amount

$-\quad 2.06$

$-\quad 10.44$

Percentage of GDP

$-\quad 88 \%$

$-\quad 73 \%$

Memo: Actual size of central

bank's balance sheet

$0.09 \quad 0.22$

$0.91 \quad 2.09$

Percentage of GDP

$6 \quad 15$

$7 \quad 15$

Source: Bank of England Financial Stability Report (2009, June, p.20).

Three items are of particular note from the balance sheet perspective adopted in this paper. First the asset purchases which include overt purchase of corporate debt, as well as indirect support via portfolio reallocation - as when the Central Bank buys government debt from financial institutions, allowing them to take on more corporate debt. Asset purchases in the US, including Mortgage Backed Securities, amount to over 3 trillion dollars, almost a third of the total support provided. This will include purchases under the provisions of the original $\$ 700$ billion TARP proposal made by Mr Paulson. For the UK, the figures include purchases under the Asset Purchase 
Facility designed to provide continued support in the form of Quantitative Easing once interest rates had reached their effective lower limit. Official purchases of troubled assets are, of course, designed to limit the fall in the price of the assets involved, providing liquidity to those in need, see Krishnamurty (2009) and Figure 4 above. $^{21}$

Second the capital injections, amounting to between four and five percent of GDP in both countries. These would seem to correspond broadly-speaking to the Chapter 11 style intervention described above - officially coordinated balance sheet support designed to prevent industry-wide insolvency. It is interesting to note that, despite the initial focus on asset purchases in the U.S., such capital injections constitute a larger fraction of the total support in the U.S. than in the U.K.

Finally, current direct lending to financial institutions, in the top line of the table, which has eased credit conditions by broadening the range of collateral accepted by the central bank, Krishnamurthy (2009).

This official support has been largely directed at the financial sector itself; and Bean (2009) concludes his Schumpeter Lecture with a call to develop macroeconomic models including financial intermediation, replete with distorted incentives and problems of information. Simple iconic models may be useful, in the meantime, to study the implosive dynamics of systems under stress and how to check them. ${ }^{22}$

\footnotetext{
${ }^{21}$ To relate these figures to the KM model, one would have to treat the financial intermediaries as raising funds for Small Business and consolidate these two sectors; likewise, to consolidate the Government with the " deep-pocket" investors.

${ }^{22}$ Ex-ante, preventive measures, in the form of Pigovian taxes on highly leveraged institutions, are discussed in Korinek (2009).
} 


\section{References}

Abreu, D and M.K. Brunnermeier (2003). "Bubbles and Crashes," Econometrica, 71(1), pp. 173-204.

Bean, C. (2009). "The Great Moderation, the Great Panic and the Great Contraction," Schumpeter Lecture presented at Annual Congress of the European Economic Association, Barcelona, 23-27 August.

Blanchard, O. (2008). "Discussion of Cúrdia and Woodford," Bank for International Settlements Annual Conference, "Whither Monetary Policy?” Lucerne, Switzerland, 26-27 June

Cúrdia, V. and M. Woodford (2008). "Credit Market Frictions and Optimal Monetary Policy," paper presented at Bank for International Settlements Annual Conference, “Whither Monetary Policy?” Lucerne, Switzerland, 26-27 June.

Edison, H., P. Luangaram, and M. Miller (2000). “Asset Bubbles, Leverage and 'Lifeboats': Elements of the East Asian Crisis,” Economic Journal, 110, pp. 309-334.

Bank of England Financial Stability Review (2009). Vol. 24 (June).

Furman, J. and J.E. Stiglitz (1998). "Economic Crises: Evidence and Insights from East Asia," Brookings Papers on Economic Activity, 29(2), pp. 1-136.

Gai, P., S. Kapadia, S. Millard, and A. Perez (2008). "Financial Innovation, Macroeconomic Stability and Systemic Crises," Economic Journal, 118, pp. 401-426.

Geanakoplos, J. (2003). "Liquidity, Default, and Crashes: Endogenous Contracts in General Equilibrium," Advances in Economics and Econometrics: Theory and Applications, Eighth World Conference, Econometric Society Monographs, vol. 2, pp.170-205.

Gorton, G. B. (2008). “The Panic of 2007.” NBER WP Number 14358 (September). 
Hellmann, T., K. Murdock, and J.E. Stiglitz (2000). ”Liberalization, Moral Hazard in Banking and Bank Regulation: Are Capital Requirements Enough?' American Economic Review, 90(1), pp. 147-65.

Kiyotaki, N. and J. Moore (1997). “Credit cycles,” Journal of Political Economy, 105, (April), pp.211-248.

Koo, R.C. (2008). The Holy Grail of Macroeconomics: Lessons from Japan's Great Recession, Singapore: J. Wiley.

Korinek, A. (2009). "Systemic Risk-Taking: Amplification Effects, Externalities, and Regulatory Responses," paper presented at IDB Meeting, BCA, Buenos Aires, 30 September.

Krishnamurthy, A. (2003). "Collateral Constraints and the Amplification Mechanism," Journal of Economic Theory, 111(2), pp. 277-92.

Krishnamurthy, A. (2009). "Amplification Mechanisms in Liquidity Crises," American Economic Journal, forthcoming.

Laibson, D. (2009). "Bubble Economics," Frank Hahn Lecture at the Royal Economic Society Annual Meetings, University of Surrey, 20-22 April.

Lorenzoni, G. (2008). "Inefficient Credit Booms," Review of Economic Studies, 75, pp.809-833.

Miller, M. and J.E. Stiglitz (1999). "Bankruptcy Protection Against Macroeconomic Shocks: the Case for a 'Super Chapter 11,"' Unpublished. Available at http://www2.warwick.ac.uk/fac/soc/csgr/research/keytopic/global/milrstig.pdf.

Shiller, R. J. (2008). The Subprime Solution, Princeton, NJ: Princeton University Press. 
Shirakawa, M. (2009). “International Policy Response to Financial Crises,” paper presented at the Federal Reserve Bank of Kansas City Symposium on "Financial Stability and Macroeconomic Policy,” Jackson Hole, 20-22 August.

Silonov, V. V. (2008). The Kiyotaki and Moore Model: Introduction of Dynamic Margin, MSc Dissertation, University of Warwick.

Stiglitz, J.E. (2006). Making Globalization Work, London: Allen Lane.

Stiglitz, J.E. (2008). “We Aren't Done Yet: Comments on the Financial Crises and Bailout," Economists' Voice, The Berkeley Electronic Press, October.

Stiglitz, J.E. and B. Greenwald (2003). Towards a New Paradigm in Monetary Economics, Cambridge: Cambridge University Press.

Williamson, J. (2009). “Understanding the Crisis of 2007-09," Presidential Address to Section F of the British Science Association, University of Surrey, 10 September.

Wolf, M. (2009). “Japan's lessons for a world of balance-sheet deflation,” Financial Times, 17 Feb.

Woodford, M. (2003). Interest and Prices, Princeton, NJ: Princeton University Press.

Zingales, L. (2008). “Why Paulson is Wrong,” Economists' Voice, The Berkeley Electronic Press (October). 